\title{
Hydrographic Variability off the Rías Baixas (NW Spain) During the Upwelling Season
}

\author{
X. A. Alvarez-Salgado, G. Rosón, F. F. Pérez and Y. Pazos \\ Instituto de Investigacións Mariñas, Vigo, Spain
}

\begin{abstract}
During the Galicia $X$ cruise, from May to October 1989 an intensive collection of hydrographic data was carried out at a single station on the shelf off the western coast of Galicia. It allows us to follow the response of the water column to the intermittent equatorward wind stress during the upwelling season. Upwelling events occur with biweekly periodicity, bringing Eastern North Allantic Water (ENAW) to the subsurface layer at our station. A trend of the thermohaline properties of the upwelled water to increase in time was observed. This seems to be mostly due to the southwestward displacement of the origin of this water mass during the year. Although the saltier and warmer ENAW is less nutrient-rich, nutrient levels increase because of the rapid remineralization of organic matter from the Rías, which takes place in the bottom water on the shelf.
\end{abstract}

\section{INTRODUCTION}

The Rías Baixas are four coastal embayments in the western coast of Galicia (NW Spain). .Inner circulation as positive estuaries [Fraga and Margalef, 1979] and water exchange with the shelf are both affected by wind-driven upwelling that is common along the eastern boundary of the North Atlantic between $10^{\circ}$ and $44^{\circ} \mathrm{N}$ [Wooster et al., 1976]. At the latitudes of the Rías Baixas $\left(42^{\circ}-43^{\circ} \mathrm{N}\right)$, the seasonal cycle in wind direction follows the position and strength of the Azores High. From November to March, coastal winds are predominantly poleward (downwelling), and from April to October equatorward (upwelling) of variable intensity.

Since the existence of upwelling was pointed out by Molina [1972], several workers have studied its spatial variability along the Galician coast: González et al. [1980] in September 1978; Fraga [1981] in September 1974, August 1975, June 1976 and October 1977; Blanton et al. [1984] in April 1981; González et al. [1984] in June 1979; and McClain et al. [1986] in April 1982. These works reveal that the zones of intensified upwelling are off Cape Finisterre and the Rías Baixas. Blanton et al. [1987] briefly described the seasonal evolution of this phenomenon. They found good agreement between the hydrographic variability at the mouth of the Ria of Vigo during 1977 [data from fortnightly sampling by Fraga and Mourino, 1978], changes in sea level height and upwelling index.

Upwelling events result in the movement of Eastern North Atlantic Water (ENAW) across the shelf and into the rias along the bottom [Fraga, 1981]. In addition, upwelling favorable winds tend to increase the residual flows into the estuaries [Blanton et al., 1984; Prego and Fraga, 1992] and, consequently, the net influx of nutrient-rich deeper water. This fertilization leads to the high primary production which supports

Copyright 1993 by the American Geophysical Union.

Paper Number $93 \mathrm{JC} 00458$.

0148-0227/93/93JC-00458\$05.00 the most intensive edible mussel culture industry in the world [Tenore et al., 1982]. A good positive correlation was found by Blanton et al. [1987] between quality (meat content) of mussels cultured in Ría of Arousa and the mean April-September upwelling index.

Due to the estuarine circulation, part of the biomass produced in the rias is exported to the shelf in the outgoing surface current. At the same time it sinks, reaching the bottom layer over the shelf, where remineralization takes place. These nutrients return to the rias in the ingoing current [Fraga, 1981]. During the Galicia IV cruise in October 1977 it was observed that nitrate levels in waters of the same thermohaline properties were almost double in the coastal shelf than in the surrounding open ocean [Fraga, 1981]. Since then, several authors [e.g., Estrada, 1984; Figueiras et al., 1986] turned to that explanation to justify the high concentrations of remineralized nutrients at the end of the upwelling period.

However, a detailed estimate of the significance of these processes throughout the upwelling season has never been made. Therefore, In this work we followed the short-time evolution of the thermohaline properties and chemical composition in the water column off the Rías Baixas during the upwelling season of 1989 , to examine this remineralization hypothesis more deeply.

\section{MATERIALS AND METHODS}

From May 22 to October 301989 , water samples were taken twice a week at station E11, 42 $18 \mathrm{~N}, 8^{\circ} 57^{\prime} \mathrm{W}$ (see Figure 1). This station, $75 \mathrm{~m}$ deep, is located on the shelf, about $9 \mathrm{~km}$ from the mouth of the Ria of Pontevedra and $39 \mathrm{~km}$ from the shelf break.

Samples were taken at the standard depths of $0,10,20,30,40$, 50 and $70 \mathrm{~m}$ with $5 \mathrm{~L}$ PVC Niskin bottles, provided with rotating thermometer frames for temperature and depth control. Salinity was calculated from conductivity measurements with the AUTOSAL 8400A [Unesco, 1981]; dissolved oxygen was determined by Winkler potentiometric titration; nitrate and phosphate were analyzed on board by Technicon AAII SFA systems according to Hansen and Grasshoff [1983] with some 


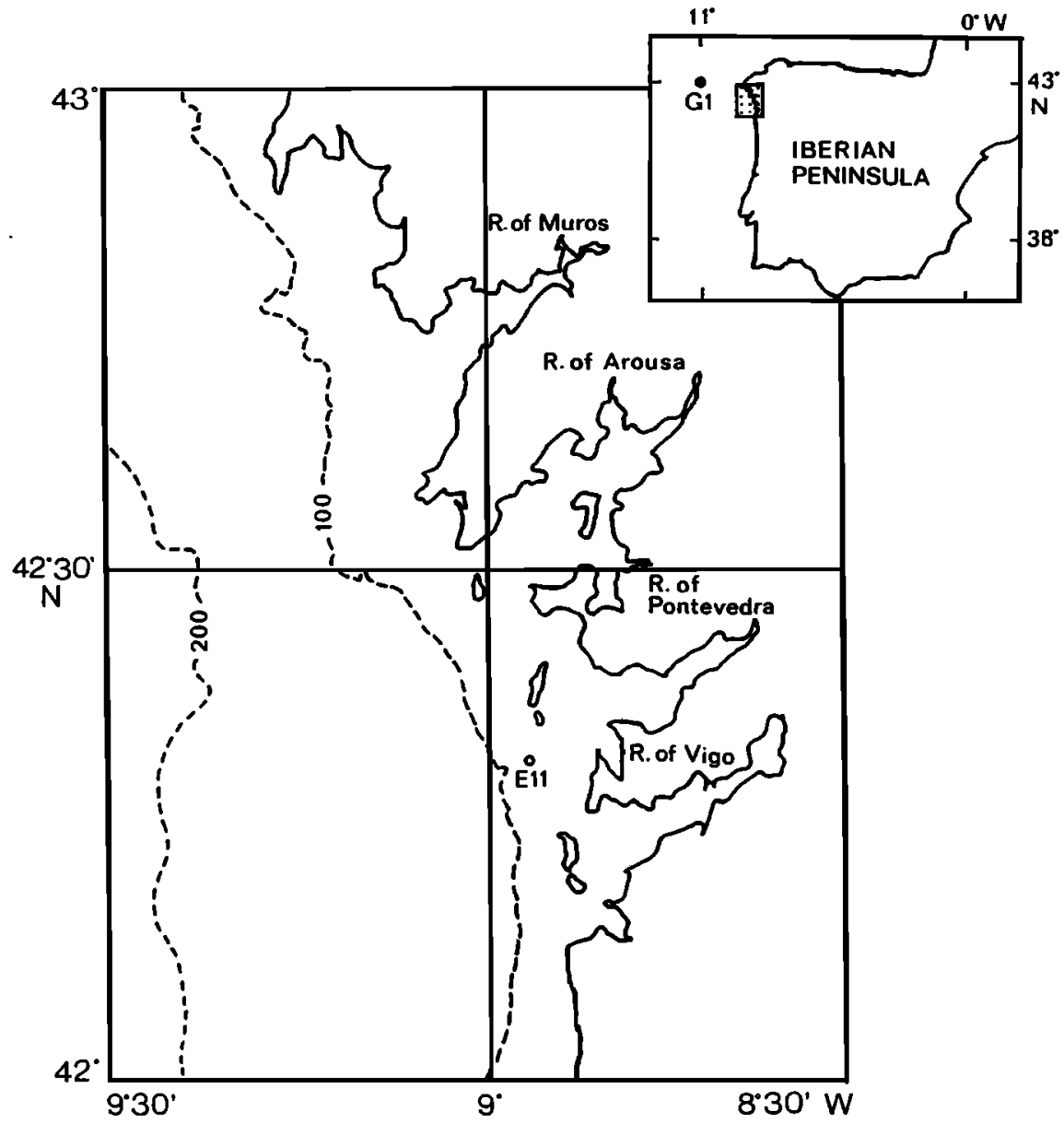

Fig. 1. Galician Rias Baixas coast with the 100 and $200 \mathrm{~m}$ isobaths and the hydrographic E11 (open circle) and geostrophic $\mathrm{Gl}$ (solid circle) stations.

small modifications [Mouriño and Fraga, 1985; AlvarezSalgado et al., 1992]; and pH (National Bureau of Standards) was measured with an Orion Ross combined $\mathrm{pH}$ electrode. It was referred to $15^{\circ} \mathrm{C}$ according to Pérez and Fraga [1987].

Upwelling indices, $I_{w}$, were taken from Lavin et al. [1990]. These were obtained from geostrophic wind calculations [Bakun, 1973] at station GI, 43 N, $11^{\circ} \mathrm{W}$ (see Figure 1). Negative values indicate downwelling.

\section{RESULTS AND DISCUSSION}

The sampling grid, both in depth and time, is sufficiently intensive to characterize the different water bodies and to determine the intermittent upwelling events which take place at station E11 during this period in relation to the wind stress. Nutrient levels in the bottom layer, occupied mostly by ENAW, allow us to test Fraga's hypothesis that remineralization of organic matter from the rias can explain their actual concentrations, higher than those expected on the basis of the thermohaline properties of this water mass alone.

\section{Changes in Time of Thermohaline Properties}

Water samples that belong to ENAW over the period studied have been selected from the analysis of the daily $T / S$ diagrams.
The following linear regression between salinity and temperature was obtained for all these points (see Figure 2):

$$
\begin{gathered}
S=35.561( \pm 0.012)+0.099( \pm 0.004)(T-11) \\
n=97 \quad r^{2}=0.88
\end{gathered}
$$

It is in good agreement with the equation $S=35.586+0.106$ (T - 11). This is what Fraga et al. [1982] considers the typical NACW that upwells off the Rías Baixas, as distinct from that which appears off the Rias Altas, to the north of Cape Finisterre, called Bay of Biscay Central Water (BBCW). According to Rlos et. al [1992], the former is subtropical ENAW $\left(E_{N A W}\right)$ and the latter subpolar ENAW (ENAW ) in origin. ENAW $t$ is formed at a front in the Azores and ENAW $p$ north of $46 \%$, in the Celtic Sea. Off Cape Finisterre a subsurface front forms between them following a pattem of lateral mixing.

If the salinity of the ENAW upper layer, i.e., the maximum of the salinity profile, at station E11 is fitted versus time (see Figure 3) an increase is clearly observed. The linear regression below, between salinity and time, can be obtained:

$$
\begin{gathered}
S=35.632( \pm 0.018)+0.0007( \pm 0.0001) J \\
n=41 \quad r^{2}=0.70
\end{gathered}
$$




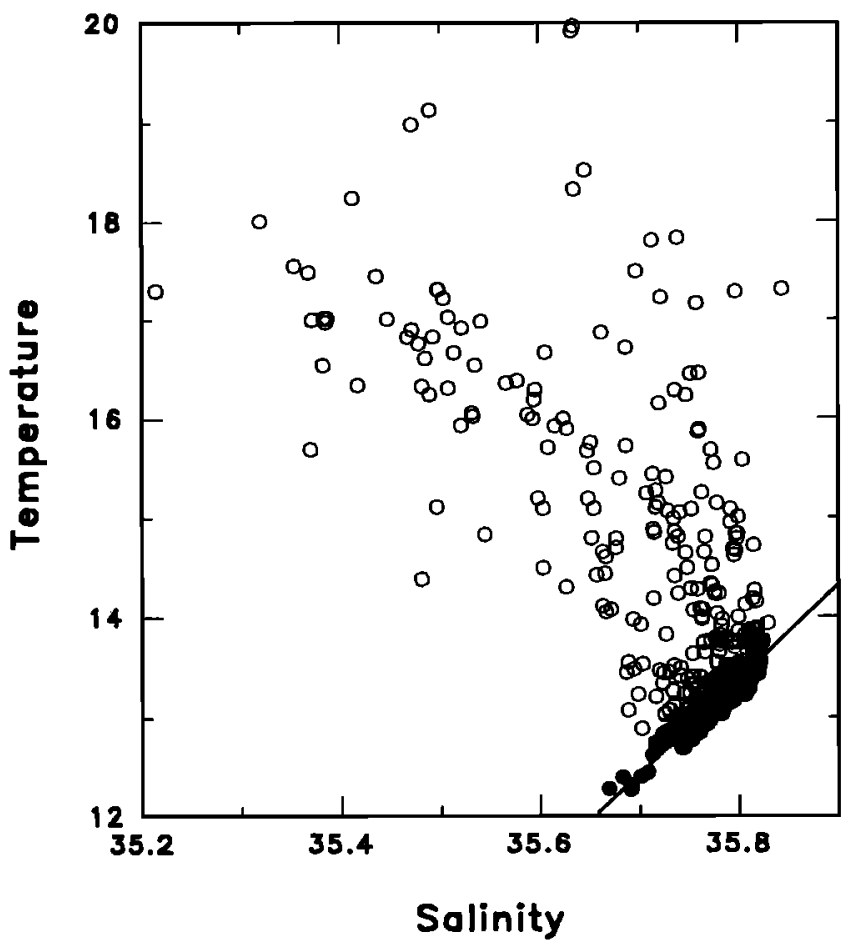

Fig. 2. TS diagram for all samples over the study period: surface data (open circle), ENAW data (solid circle) and Fraga's NACW regression line (solid line)

Where $J$ is the Julian day, starting on January $1,1989$.

According to the positive covariance between salinity and temperature for the ENAW (1), the latter may follow the same pattern of increasing with time during the upwelling season:

$$
\begin{gathered}
T=11.81( \pm 0.16)+0.0065( \pm 0.0006) J \\
n=41 \quad r^{2}=0.74
\end{gathered}
$$

In consequence, during this period ENAW became saltier and warmer. This phenomenon is neither due to local climatic factors nor continental inputs, but is an intrinsic quality of the ENAW upwelled from offshore as described recently by Rios et al. [1992]. They argue that this is because ENAW $t$ comes from a southwestward position, less influenced by winter mixing processes, during the year. Table 1 shows the good agreement found between salinity data presented by Rios et al. [1992], corresponding to several months of different years, and our own. The actual salinity and temperature at the salinity maximum are probably a result of the variability in the depth from which offshore ENAW upwells onto the shelf. In this sense, the less saline, colder and nutrient-richer waters come from greater depths [Fraga et al., 1982]. These paramenters can also depend on other oceanographic factors such us the degree of wind driven mixing within the surface layer, and the position of the Cape Finisterre subsurface front, which can cause $E_{N A W_{p}}$ to upwell in the Rias Baixas.

This increase in salinity and temperature of $\mathrm{ENAW}_{\mathrm{t}}$ during the year seems to follow a progressive trend. However, a more detailed analysis of the $T / S$ diagrams shows that between July 31 and August 7 a sudden change in thermohaline properties took place (see Figure 4). Salinity of ENAW $t$ on August 7 is much higher than on July 31. A mixture of these two situations can be observed on August 3.

As a result of this increase in salinity (2) and temperature (3) there is a linear decrease with time in $\sigma_{t}$ which can be reduced to the simple linear equation (4).

$$
\sigma_{t}=27.13-0.00082 J
$$

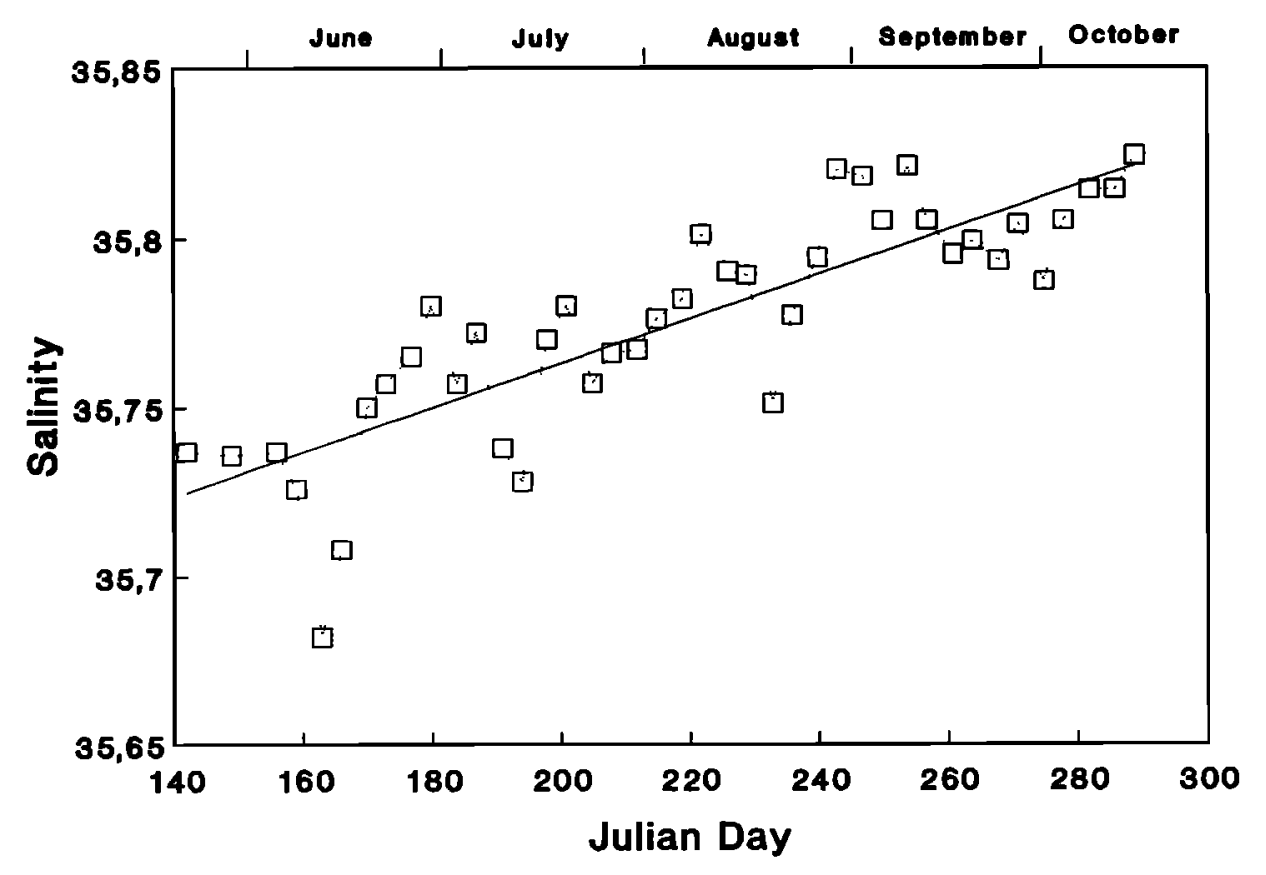

Fig. 3. Increase in time trend of ENAW $\mathrm{t}_{\mathrm{t}}$ upper layer salinity at station E1 1. 
TABLE 1. Comparison Between Maximun Salinity Values of ENAW Reported by Rios et al. [1992] and Monthly Averaged Values in This Work

\begin{tabular}{|c|c|c|c|c|}
\hline \multicolumn{3}{|c|}{ Rios et al. [1992] } & \multicolumn{2}{|c|}{ This work } \\
\hline Position & Date & Salinity & $\begin{array}{c}\text { Month in } \\
1989 \text { at } \\
42^{\circ} 18 \mathrm{~N}, 8^{\circ} 57 \mathrm{~W}\end{array}$ & Salinity \\
\hline $42^{\circ} 00^{\prime} \mathrm{N}, 9^{\circ} 46^{\prime} \mathrm{W}$ & Feb. 1984 & 35.552 & & \\
\hline \multirow[t]{2}{*}{$42^{\circ} 08 \mathrm{~N}, 8^{\circ} 59^{\prime} \mathrm{W}$} & May. 1982 & 35.735 & May & 35.725 \\
\hline & & & June & 35.745 \\
\hline \multirow[t]{2}{*}{$41^{\circ} 54 \mathrm{~N}, 9^{\circ} 41^{\prime} \mathrm{W}$} & Jul. 1984 & 35.775 & July & 35.760 \\
\hline & & & Aug. & 35.781 \\
\hline \multirow[t]{2}{*}{$41^{\circ} 52 \mathrm{~N}, 9^{\circ} 39^{\prime} \mathrm{W}$} & Sep. 1986 & 35.789 & Sept. & 35.801 \\
\hline & & & Oct. & 35.820 \\
\hline $42^{\circ} 05^{\mathrm{N}}, 9^{\circ} 42^{\prime} \mathrm{W}$ & Nov. 1988 & 35.918 & & \\
\hline $41^{\circ} 54 \mathrm{~N}, 9^{\circ} 39^{\prime} \mathrm{W}$ & Dec. 1983 & $35 . .962$ & & \\
\hline
\end{tabular}

As can be observed from the shaded zones in Figure 5, ENAW remains in the water column almost throughout the period studied. However, the depth to which this water rises (an intrinsic sign of upwelling intensity) appears as a succession of peaks and valleys that correspond to situations of stress and relaxation of upwelling, respectively. They show a periodicity of $14 \pm 4$ days, as can be estimated from the time interval between consecutive peaks, and are weakly related to the upwelling index, $I_{w}$, obtained from geostrophic winds (see Figure 6). The stress (higher $I_{w}$ values) and relaxation (lower $I_{w}$ ) cycle in the intensity and direction of winds is only roughly superimposed on the variability of the position of the ENAW upper layer. It is necessary to take into account that the inertia of coastal circulation to wind stress is about 3 days and the relaxation is even slower [MCClain et al., 1986]. Furthermore, disturbances of wind-driven upwelling due to the topographic effects of Cape Finisterre can take place, as theoretically predicted by Blanton et al. [1984]. Thus, Blanton et al. [1987] found the best correlation between wind stress and sea level in Ría of Vigo (another good estimate of upwelling) with bi-weekly averages.

Slightly negative values of $I_{w}$ were found some days during summer. In spite of this, the poleward winds were not persistent enough to provoke downwelling, but only relaxation of upwelling. The mean April-September 1989 upwelling index was $380 \mathrm{~m}^{3} /(\mathrm{s} \mathrm{Km}$ coast), versus a long term average of 340 $\mathrm{m}^{3} /(\mathrm{s} \mathrm{Km}$ coast) over the same months from 1966 to 1989 [Lavin et al., 1990]. However, the power and steadiness of southwesterly winds from October 15 were able to provoke a drastic hydrographic change at our station: ENAW withdrew from the shelf and the less saline and warmer surface water occupied the water column, leading to a typical downwelling situation.

\section{Chan.ge in time of chemical properties}

As can be seen in Figures $7 a$ and $7 b$, changes in the nitrate and phosphate profiles are closely related to changes of the $\sigma_{t}$ profile. This is the expected behavior, taking into account the high nutrient concentrations of ENAW. Likewise, at the end of

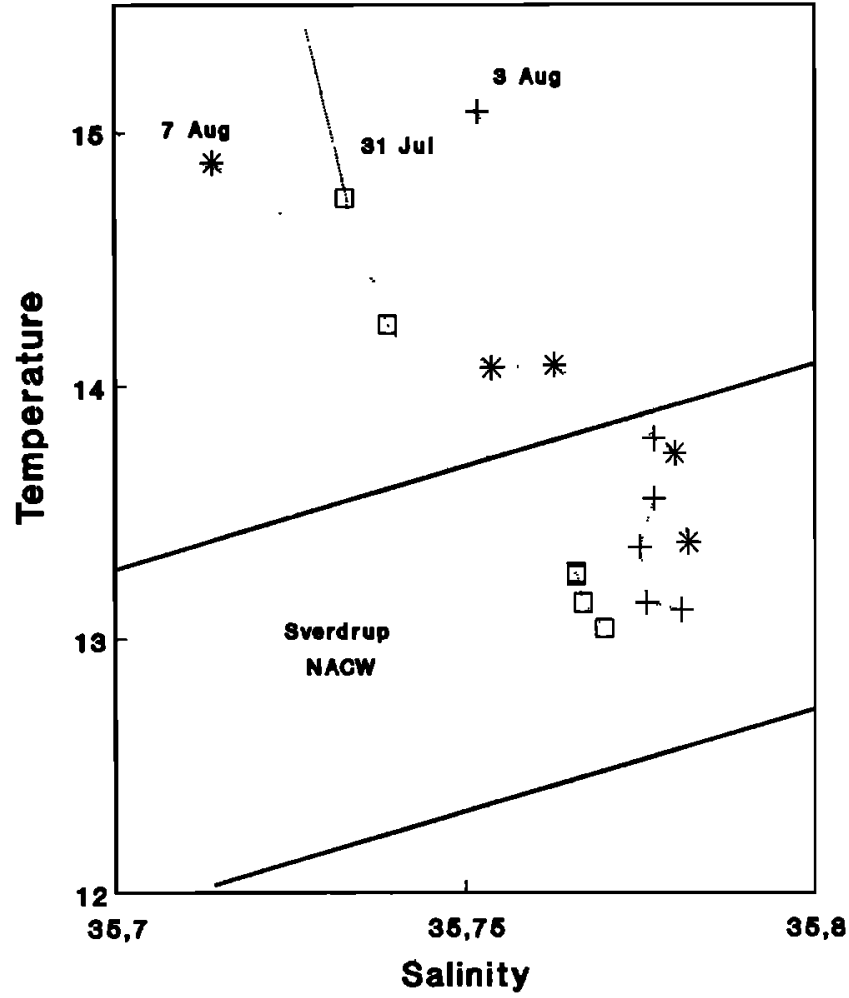

Fig. 4. Comparative TS diagram of July 31 and August 3 and 7 at station E11.

the period studied, when downwelling occurs, the whole water column is occupied by nutrient-depleted surface waters. The inverse pattern is observed with dissolved oxygen and $\mathrm{pH}$ (see Figure $7 c$ and $7 d$ ). Good correlations were found among these chemical parameters with $r^{2}=0.92$ for $\mathrm{NO}_{3}-/ \mathrm{HPO}_{4}{ }^{2-}, r^{2}=0.80$ for $\mathrm{O}_{2} / \mathrm{HPO}_{4}{ }^{2-}$ and $r^{2}=0.87$ for $\mathrm{O}_{2} / \mathrm{pH}$.

Although ENAW becomes saltier and warmer from May to October and, as a consequence, less rich in nutrient salts, their concentrations at station E1l instead of diminishing show a small increase in time. Following, e.g., the evolution of the 0.5 $\mu \mathrm{mol} \mathrm{kg}-1$ isoline in the phosphate profile, at the beginning of the period it is within the ENAW domain, but at the end it is clearly not, revealing that phosphate levels are higher in the water below. The same pattem can be observed for the isolines of $5 \mu \mathrm{mol} \mathrm{kg-1}$ in the nitrate, of $200 \mu \mathrm{mol} \mathrm{kg-1}$ in the oxygen and of 8.08 unit in the $\mathrm{pH}$ profiles. This is due not only to the ageing of ENAW in the open ocean but also to the remineralization of the particulate organic matter which, coming from the Rias in the surface layer, sinks over the shelf [Fraga, 1981].

This is a consequence of the water circulation in the Rías which acts as a positive partially mixed estuary [Fraga and Margalef, 1979]. Water that flows into the Rias along the bottom is enriched in nutrient salts because of this remineralization. Then there is an enhancement of primary production inside the Rias, and the particulate organic matter exported to the shelf increases. Prego and Fraga [1992] have estimated an exchange of about $10^{6} \mathrm{~m}^{3} \mathrm{~s}^{-1}$ in summer for Ría of Vigo. Probably, this would lead to a feedback cycle if 

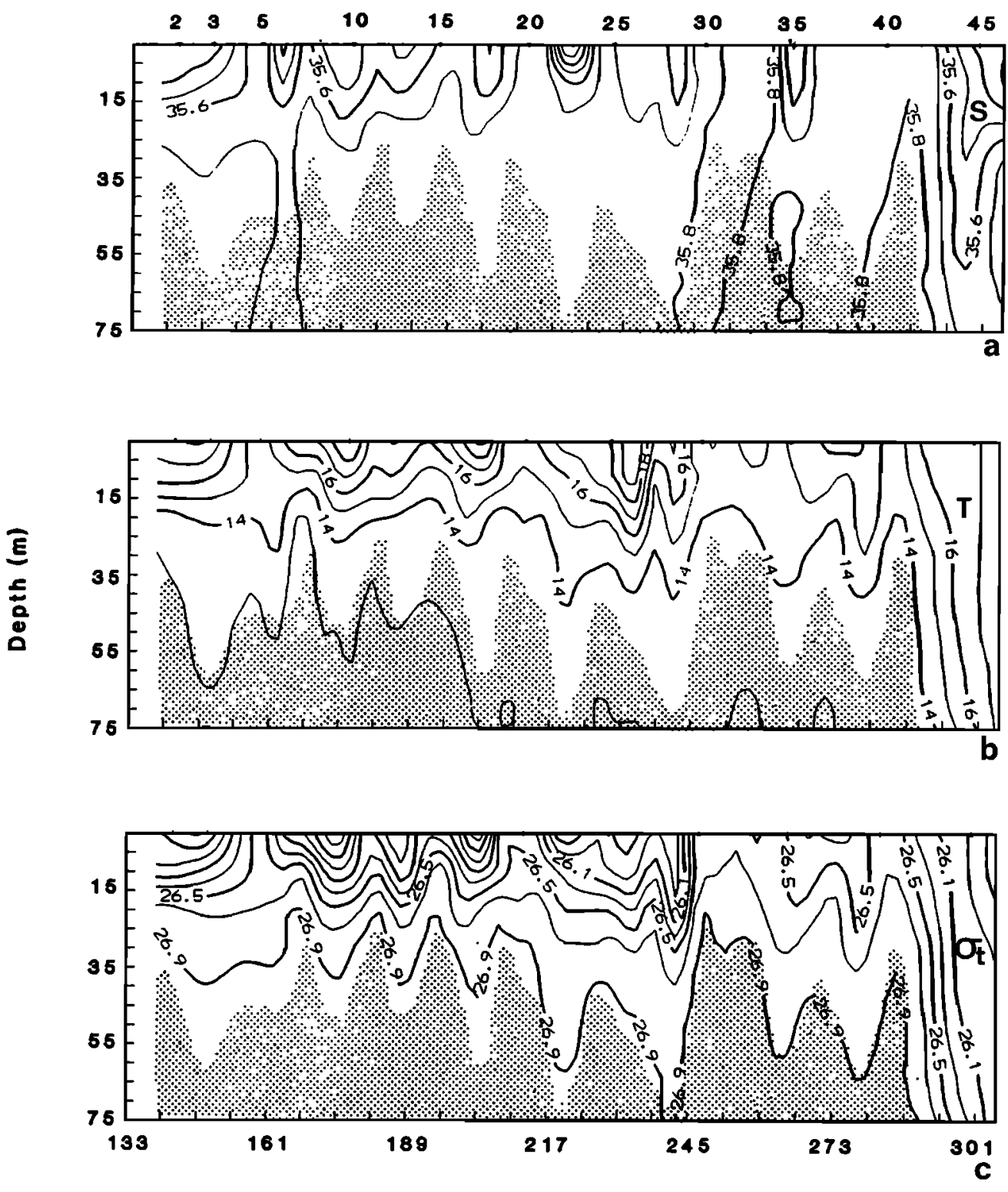

Julian Day

Fig. 5. Evolution in time of $(a)$ salinity, $(b)$ temperatule, and $(c) \sigma_{t}$ profiles at station E11. The shaded zone represents the $\mathrm{ENAW}_{\mathrm{t}}$ domain.

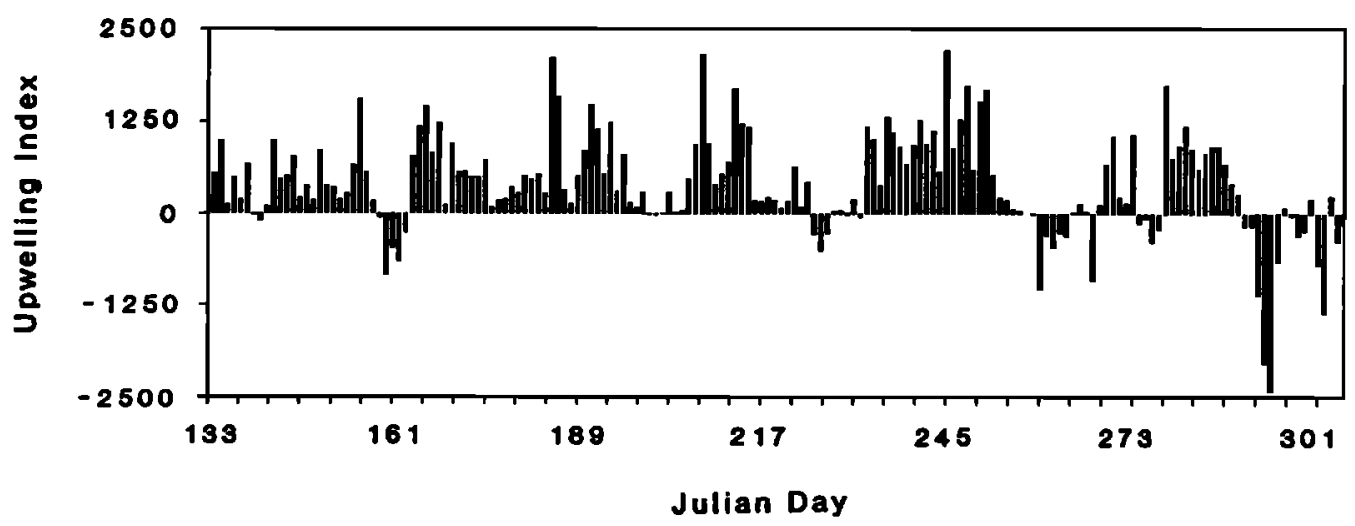

Fig. 6. Daily average Upwelling index versus time calculated from a geostrophic cell centered at 43 o, 11 'W (station GI, Figure 1). 

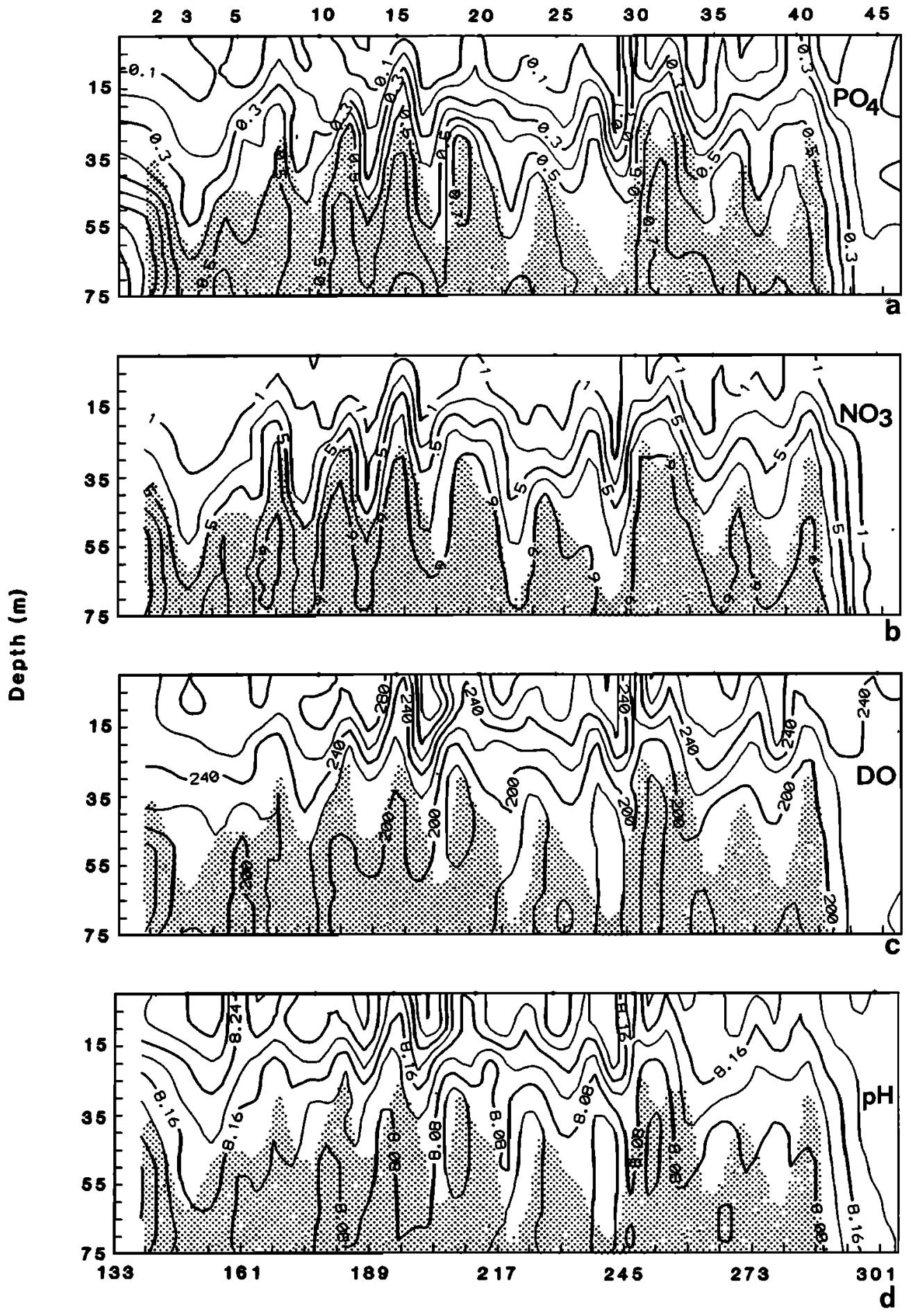

Julian Day

Fig. 7. Evolution in time of (a) phosphate, (b) nitrate, (c) dissolved oxygen, and (d) $\mathrm{pH}$ profiles at station E11. The shaded zone represents the $\mathrm{ENAW}_{t}$ domains.

downwelling did not interrupt it. In Figure 8 a simple schematic of this model is shown. Coupled with this water circulation pattern between coastal shelf and Rias, there is a wind driven equatorward movement of the surface layer and, under it, a poleward displacement of ENAW $\mathrm{t}$ along the coast which also favors nutrient accumulation [Fraga et al., 1982].

To test the validity of such a model, we compare nutrient levels in the bottom layer on the shelf with those found offshore in water of the same thermohaline properties usually in a deeper layer. The difference between the two concentrations is the nutrient enrichment as a consequence of regeneration processes. It implies an oxygen consumption which can be theoretically estimated assuming a molar ratio for remineralization. This calculated oxygen consumption may be equal to the decrease 


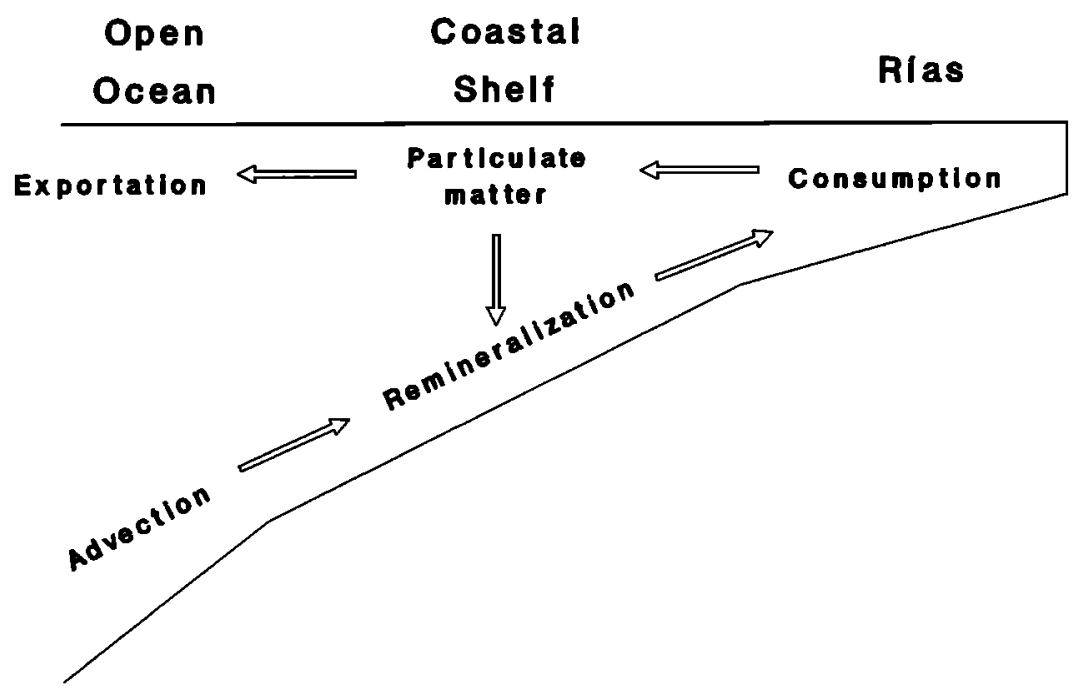

Fig. 8. Simple scheme of Rias-coastal shelf water circulation model.

observed in its concentration on the shelf with respect to that of the same water in the open ocean. Therefore, a nutrient anomaly due to regeneration on the shelf can be defined as

$$
[X]^{s}=[X]^{t}-[X]^{O}
$$

where: $[X]^{s}$ is nutrient concentration increase in ENAW at station E11 due to remineralization over the shelf, $[X]^{t}$ is actual nutrient concentration at station E11 and $[X]^{o}$ is nutrient concentration in ENAW of the same salinity and temperature in the open ocean. The same kind of anomaly can be defined for oxygen consumption.

Nutrients and dissolved oxygen levels of ENAW in the open ocean off Rías Baixas correlate well with the thermohaline properties of this water mass from year to year. Since measurements of $[X]^{\circ}$ were not carried out for the period studied, they have been estimated from those found during the Galicia VIII cruise (July 11 to August 8 1984). The following linear regressions for phosphate and dissolved oxygen versus temperature, including all the ENAW samples between $42^{\circ}$ and $43{ }^{\circ} \mathrm{N}$ and from the slope to $10^{\circ} \mathrm{W}$, have been obtained:

$$
\begin{gathered}
{\left[\mathrm{HPO}_{4}{ }^{2-}\right]^{o}=3.34( \pm 0.05)-0.232( \pm 0.009) T} \\
n=86 \quad r^{2}=0.89 \\
{\left[\mathrm{O}_{2}\right]^{o}=122.5( \pm 6.3)-9.04( \pm 1.13) T} \\
n=86 \quad r^{2}=0.43
\end{gathered}
$$

These experimental equations take into account the preformed nutrient and preformed dissolved oxygen of ENAW when it originated the preceding winter and the nutrient regeneration and oxygen consumption due to remineralization in the open ocean. They may be introduced into (5) to obtain $\left[\mathrm{HPO}_{4}{ }^{2-}\right]^{s}$ and $\left[\mathrm{O}_{2}\right]^{s}$ which includes only the processes on the coastal shelf.

We assume a molar ratio of $\left[\mathrm{O}_{2}\right] /\left[\mathrm{HPO}_{4}{ }^{2-}\right]=-175$ for remineralization of organic matter on the coastal shelf off Rías Baixas. This was obtained by Rios and Fraga [1987] from the elemental composition of natural phytoplankton taken from Ria of Vigo and it coincides with that estimated from Redfield numbers by Takahashi et al. [1985]. The evolution in time of $175\left[\mathrm{HPO}_{4}{ }^{2-}\right]^{s}$ (theoretical oxygen consumption) and $-\left[\mathrm{O}_{2}\right]^{s}$ (experimental) at $70 \mathrm{~m}$ depth are shown in Figure 9. A clear pattern of increase for phosphate is observed: from about $30 \%$ of the total nutrient concentration in May to $70 \%$ in October is due to the cyclical remineralization-production process described above. This hypothesis is confirmed by the fact that the theoretical oxygen consumption that we suppose to be due to such a process correlates well with the experimental values $\left(r^{2}=\right.$ 0.79).

\section{SUMMARY}

Upwelling of ENAW $\mathrm{t}_{\mathrm{t}}$ from offshore to the coastal shelf and Rias took place intermittently throughout the period studied, except from October 15, when a marked downwelling event was observed. These phenomena follow a complex pattern in which the power and direction of the winds and local enhancement due to bathymetric features (Cape Finisterre topographic effect) seem to drive it. Upwelling Indices quantitatively correlate inversely with the depth of maximum salinity, an intrinsic indication of the upwelling intensity.

A change in the themohaline properties of $\mathrm{ENAW}_{t}$ on the coastal shelf during the upwelling season was found. More than $70 \%$ of $T / S$ variability in the salinity maximum was explained by a linear fit versus time: $0.02 \mathrm{PSU} / m o n$th in salinity and $0.20^{\circ} \mathrm{C} /$ month in temperature from $35.716 \mathrm{PSU}$ and $12.59^{\circ} \mathrm{C}$ on May 1. As a result, $\sigma_{t}$ decreased 0.02 units/month from 27.03. This is due to the arrival of ENAW $t$ at these latitudes from a more and more southeastward position during the year.

On the coastal shelf off Rías Baixas, coupling takes place between two perpendicular water circulations, one along the coast equatorward in the surface layer and poleward of ENAW and the other from the Rias to the shelf at the surface and in the opposite direction at the bottom (positive estuarine circulation). As a result there is an increase in time of the nutrient levels in $\mathrm{ENAW}_{\mathrm{t}}$ on the shelf due to remineralization of particulate organic matter which sinks from the surface water exported by the Rias. So just before downwelling interrupted the 


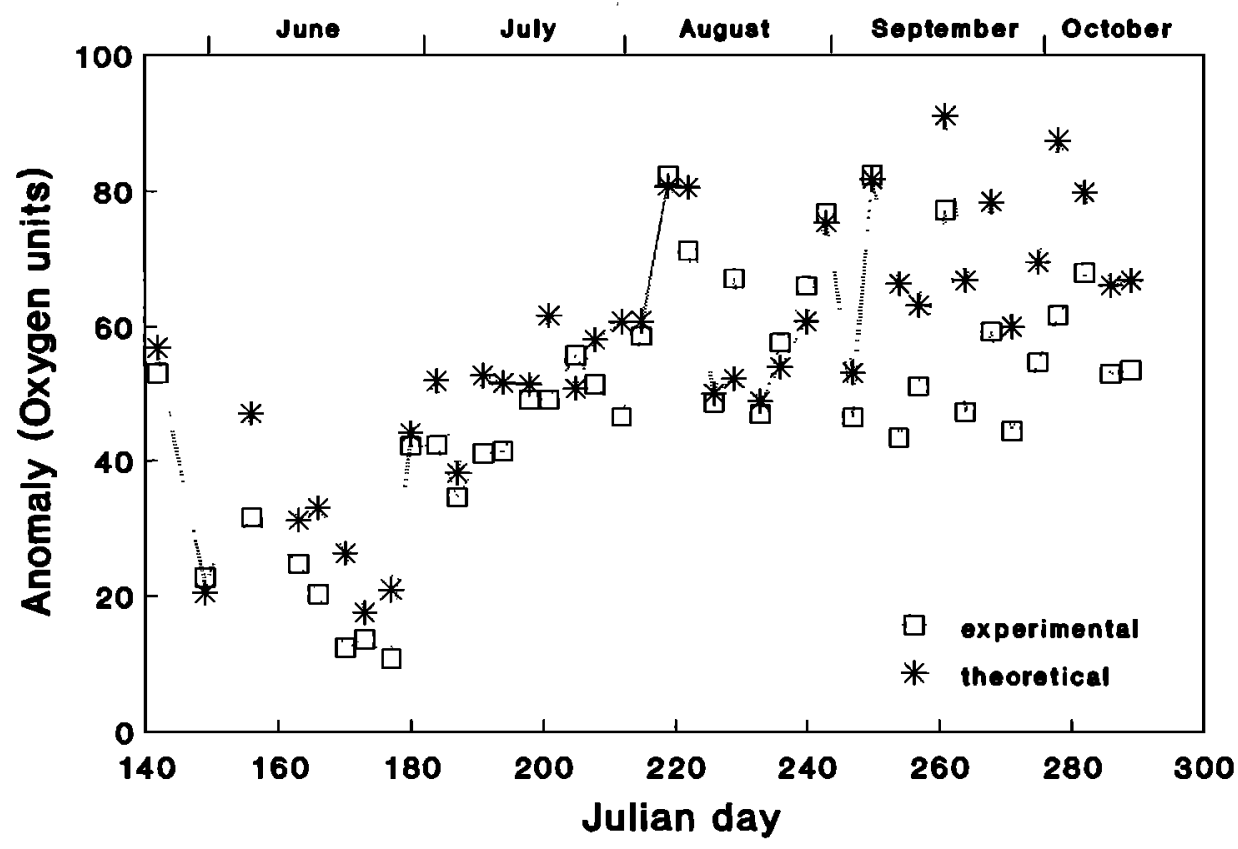

Fig. 9. Evolution in time of theoretical $\left(175\left[\mathrm{HPO}_{4}{ }^{2}\right]^{s}\right)$ and experimental $\left(\left[\mathrm{O}_{2}\right]^{s}\right)$ oxygen consumption due to remineralization processes over the shelf at $70 \mathrm{~m}$ depth.

photosynthesis-remineralization feedback cycle between the Rias and the coastal shelf, phosphate at $70 \mathrm{~m}$ depth over the shelf was more than twice the expected concentration offshore at the same isopycnal calculated from equation (6). This model is supported by the fact that theoretical and experimental oxygen consumptions due to this process correlate well $(79 \%$ of the variability) over all the period studied.

Acknowledgments. Support for this work came from CICYT grant MAR88-0245 and Conselleria de Pesca de la Xunta de Galicia. We thank all the participants in the Galicia $X$ cruise and the crew for their help. We also thank $F$. Fraga and two anonymous reviewers for providing valuable critical comments, and Ramón Penin for help in the preparation of the figures.

\section{REFERENCES}

Alvarez-Salgado, X. A., F. Fraga, and F. F. Pérez, Determination of nutrient salts by automatic methods both in sea and brackish waters: The phosphate blank, Mar. Chem., 39, 311-319, 1992.

Bakun, A., Coastal upwelling indices, west coast of North America, 1946-71, NOAA, Tech.Rep., NMFSSSRF-671, 103 pp., 1973.

Blanton, J. O., L. P. Atkinson, F. Fernández de Castillejo, and A. Lavin, Coastal upwelling off Rías Bajas, Galicia, Northwest Spain I: Hydrographic studies, Rapp. P. v. Réun. Cons. int. Explor. Mer., 183, 79-90, 1984.

Blanton, J. O., K. R. Tenore, F. Castillejo, L. P. Atkinson, F. B. Schwing, and A. Lavin, The relationship of upwelling to mussel production in the Rias on the western coast of Spain, $J$. Mar. Res., 45(2), 497-511, 1987.

Estrada, M., Phytoplankton distribution and composition off the coast of Galicia (northwest of Spain), J. Plank. Res., 6(3), 417 434, 1984.
Figueiras, F. G., F. X. Niel, and C. Mourino, Nutrientes y oxigeno en la Ria de Pontevedra (NO de Espana), Invest. Pesq., 50, 97-115, 1986.

Fraga, F., Upwelling off the Galician Coast, Northwest Spain, in Coastal Upwelling. Coastal and Estuarine Sci., Vol. 1, edited by F. A. Richards, pp. 176-182, AGU, Washington D.C., 1981.

Fraga, F., and R. Margalef, Las Rías Gallegas in Estudio $y$ Explotación del mar en Galicia, pp 101-121, Ed. Universidad de Santiago de Compostela, 1979.

Fraga, F., and C. Mouriño, Datos informativos Inst. Inv. Pesq., Rep. 6. 78 pp., Inst. de Invest. Mariñas, Vigo, Spain, 1978.

Fraga, F., C. Mouriño, and M. Manriquez, Las masas de agua en la costa de Galicia: junio-octubre, Res. Exp. Cient., 10, 51-77, 1982.

González, N., M. T. Nunes, M. L. Iglesias, y J. M. Cabanas, Introducción al estudio de la plataforma continental contigua a las rías de Arosa y Muros (NW de España). I: Estudio químico, Bol. Inst. Esp. Oceanog., 5(2), 79-87, 1980.

González, N., J. M. Cabanas, M. L. Iglesias, M. T. Nunes, J. J. González, and J. Fumega, Contribución al estudio oceanográfico de la plataforma continental frente a las rías gallegas. Bol. Inst. Esp. Oceanog., I(2), 1-10, 1984.

Hansen, H. P., and K. Grasshoff, Automated chemical analysis in Methods of Seawater Analysis, 2' ed., pp. 347-395, edited by K. Grasshoff, M. Ehrhardt and K. Kremling, Verlag Chemie, Weinheim, 1983.

Lavín, A., G. Diaz del Rio, J. M. Cabanas, and G. Casas, Afloramiento en el noroeste de la península ibérica. Indices de afloramiento para el punto $43^{\circ} \mathrm{N} 11^{\circ} \mathrm{W}$ periodo $1966-1989$, Inf. Tec. Inst. Esp. Oceanogr., 91, 40 pp. Inst. Español de Oceanogr., Madrid, 1990.

McClain, C. R., S.-Y. Chao, L. P. Atkinson, J. O. Blanton, and F. de Castillejo, Wind-driven upwelling in the vicinity of Cape 
Finisterre, Spain, J. Geophys. Res., 9](C7), 8470-8486, 1986.

Molina, R., Contribución al estudio del "upwelling" frente a la costa noroccidental de la península ibérica, Bol. Inst. Esp. Oceanogr., 152, 3-39, 1972.

Mouriño, C. and F. Fraga, Determinación de nitratos en agua de mar, Invest.. Pesq., 49, 81-96, 1985.

Pérez, F. F. and F. Fraga, The $\mathrm{pH}$ measurements in seawater on NBS scale, Mar. Chem., 21, 315-27, 1987.

Prego, R. and F. Fraga, A simple model to calculate the residual flows in a Spanish ría. Hydrographic consequences in the ria of Vigo, Estuarine Coastal Shelf Sci., 34, 603-615, 1992.

Ríos, A. F. and F. Fraga, Composición química elemental del plancton marino, Invest. Pesq., 51, 619-632, 1987.

Ríos, A. F., F. F. Pérez, and F. Fraga, Water masses in upper and middle North Atlantic ocean east of Azores. Deep Sea Res., 39(3/4), 645-658, 1992.

Takahashi, T, W. S. Broeker, and S. Langer, Redfield ratios based on chemical data from isopycnal surfaces. J. Geophys.
Res., 90, 6907-6924, 1985.

Tenore, K. R., et al., Coastal upwelling in the Rías Bajas, NW Spain: Contrasting the benthic regimes of the Rias de Arosa and de Muros, J. Mar. Res., 4O(3), 701-772, 1982.

Unesco Tenth report of the joint panel on oceanographic tables and standards, Unesco Tech. Pap. in Mar. Sci. 36, Sidney, B.C., Canada, Sept. 1980, 1981.

Wooster, W. S., A. Bakun, and D. R. Mclain, The seasonal upwelling cycle along the esastern boundary of the North Atlantic, J. Mar. Res., 34(2), 131-141, 1976.

X. A. Alvarez-Salgado, Y. Pazos, F. F. Pérez, and G. Rosón, Instituto de Investigacións Mariñas (CSIC), Eduardo Cabello, 6, 36208-Vigo (Spain). T1.: 34 (86) 2319 30, Fax: 34 (86) 2927 62, email: Yol@iim.csic.es.

(Received April 20, 1992;

revised December 14, 1992;

accepted January 12, 1993.) 